\title{
Kærlighedens dialektiker: Karakteristik af Hans Dencks kritiske spiritualisme
}

\author{
Cand. mag., ph.d. \\ Johannes Aakjar Steenbuch
}

\begin{abstract}
Hans Denck (1500-1527) is known as one of the primary characters in the South German Anabaptist movement. Denck has been characterized as a humanist with a high view of the personal freedom of human beings. Based on an analysis of Dencks concept of the difference, or even opposition, between God and human beings, his idea of yieldedness (gelassenheit), spiritualism and conception of the human will, this article argues that Dencks position should be characterized as critical spiritualism rather than humanism, in so far as the spiritual crisis inflicted on human beings by the unmediated judgment of God is at the center of Dencks thought.
\end{abstract}

Key words: Hans Denck - anabaptists - critical spiritualism - humanism - anti-humanism

Hans Denck (Johan Dengk) (c. 1500-1527) bliver ofte fremstillet som den vigtigste figur i den sydtyske døberbevægelse sammen med Hans Hut. ${ }^{1}$ I en periode blev han omtalt som "gendøbernes pave" (Bucer), men Denck er dog forholdsvist ukendt i en dansk sammenhæng. Det følgende er en introduktion til Dencks menneskesyn og hans forståelse af relationen mellem Guds og menneskets viljer. Kernepunktet i Dencks tænkning er den åndelige krise, som påføres mennesket af Guds dom, og som giver mennesket valget mellem sin egen vilje og Guds vilje, egenkærlighed og næstekærlighed. Jeg vil argumentere for, at Dencks position bedst kan kaldes en slags kritisk spiritualisme, for så vidt denne krise og derfor også Guds åbenbaring for Denck er rent åndelig og umedieret af udvortes forhold. Som led i denne karakteristik kritiserer jeg i det følgende en "humanistisk" præget læsning, der har villet gøre Denck til fortaler for menneskets iboende viljesfrihed, værdighed, skaberkraft og så videre.

Tankefigurer som Dencks kan findes senere hos fx Schwenkfeld, Tauler, Fenelon og Barclay, samt hos Holl og i Lutherrenæssancen, og ikke mindst den tidlige Barth. Det er i dag blandt andet Dencks skel-

1. Nærværende artikel læner sig især op ad følgende studier: J. Denny Weaver, Becoming Anabaptist (Pennsylvania: Herald Press 2005), 74; Werner O. Packull, Mysticism and the Early South German-Austrian Anabaptist Movement 1525-1531 (Pennsylvania: Herald Press 1977); Clarence Bauman, The Spiritual Legacy of Hans Denck (Leiden: Brill 1991). 
nen mellem det betegnede og tegnene (Kristus, og vores erfaringer og sprog derom), som synes at findes i kernen af hans spiritualisme, som gør ham interessant. Dencks overbevisning om, at det kun er muligt at følge Gud for den, der kender Gud, men at det omvendt kun er muligt at kende Gud for den, der allerede følger Gud, er ikke mindst relevant i forhold til nutidige, efter-moderne forståelser af, hvad det vil sige at være indlejret $i$ en religiøs sammenhæng og praksis, uden at den religiøse erfaring derfor reduceres til ren kontekst. ${ }^{2}$ I dette ligger en af spiritualismen afledt pragmatisme, som det i stigende grad er relevant at forstå indholdet af, efterhånden som elementer fra den "radikale reformation" tages op af især amerikanske samtidsteologer, og for så vidt man ønsker at gøre op med det forhold, at spiritualismen i en dansk sammenhæng ofte omtales rent polemisk som "sværmeri".

\section{Baggrund: Liv og lære}

Denck studerede ved universitetet i Ingolstadt fra 1517 til 1520 og blev på Johannes Oecolampadius' opfordring rektor ved St. Sebalds skole i Nüremberg i 1522. Her blev han bekendt med radikale som Hut, Karlstadt og Müntzer. Da Hans Sebald Beham, en af de såkaldt "ugudelige malere", i 1525 nævnte Hans Denck i en retssag, rettede myndighederne deres opmærksomhed mod Denck, som blev afkrævet en skriftlig bekendelse. Denck forsvarede i sin bekendelse en art spiritualisme med den indre, umedierede åbenbaring af Guds Ord som omdrejningspunkt. Frelsen sker, forklarer Denck, idet mennesket fornægter sin vilje i eftergivenhed (gelassenheit) ${ }^{3}$ og derved bliver til det, som for mennesket er intet, men som for Gud er noget. Også Dencks opfattelse af sakramenterne, skriftsyn, forholdet mellem lov og evangelium, og andet, bærer præg af spiritualisme. Guds Ord er fri af udvortes former, ikke bundet til skriften, og kan derfor åbenbare sig for mennesker, som aldrig har hørt om loven eller Kristus i udvortes tale.

Evangeliet er i sig selv ukommunikerbart og kan ikke indfanges i menneskeskabte strukturer, sprog, institutioner, liturgi og ritualer, som højst kan være tegn. Bibelen er ikke i sig selv Guds åbenbaring, men et vidnesbyrd, som kun kan tros og forstås af den, der allerede er drevet af Kristus: "Af naturen kan jeg ikke tro skriften", skriver

2. Se fx J. Denny Weaver, The Non-Violent God (Michigan: Eerdmans 2013).

3. I det følgende benyttes Dencks stavemåder. Alle henvisninger til Denck er til Hans Denck, Schriften. T. 1-3, Quellen und Forschungen zur Reformationsgeschichte /Bd. 24.6. (ed. Walter Fellman 1956). 
Denck. ${ }^{4}$ Som følge af sin bekendelse og det forhold, at han havde ladet den offentliggøre, blev Denck i 1525 forvist fra Nüremberg. Han flygtede efterfølgende til Augsburg, Strasbourg og til sidst Basel. I Strasbourg, hvortil han ankom i 1526, kom Denck på grund af sit spiritualistiske skriftsyn på kant med den schweiziske døber Michael Sattler, samt Martin Bucer, som også anklagede Denck for at benægte Kristi forsonende gerning. ${ }^{5}$ I Basel oversatte han sammen med Ludwig Hätzer profetbøgerne, som udkom i 1528 under titlen "Alle Propheten nach Hebraischer sprach". ${ }^{6}$ Før sin død som 27-årig nåede Denck at deltage i den såkaldte "martyrernes synode" i Augsburg.

Det er ikke usandsynligt, at Denck er målet for den augburgske bekendelse artikel 17's fordømmelse af "gendøberne, som mener, at der skal være ende på de fordømte menneskers og djævlenes straffe". $7 \mathrm{Da}$ dette spørgsmål er relevant for Dencks forståelse af menneskets vilje og derved hans menneskesyn og teologi i øvrigt, vil det blive berørt nedenfor, i forbindelse med diskussionen om Dencks "humanisme". Hans Denck er blevet kaldt humanist, moderne anti-dogmatiker og lignende af fx Rufus Jones, ifølge hvem den fundamentale kendsgerning om menneskets væsen for Denck var "personlig frihed". ${ }^{8}$ En nyere og mere præcis studie er W.O. Packulls, som dog gentager Jones' karakteristik, for så vidt Packull karakteriserer Denck som en humanist, for hvem mennesket ikke er fuldstændigt fordærvet af synd. Blandt andre Bauman, som lægger mere vægt på Dencks begreb om eftergivenhed (gelassenheit), har omvendt kaldt Dencks tænkning for

4. Decnk II.59. 6-11: "Von natur kan ich ye der schrifft nit glauben. Aber das in mir, nit das mein, sag ich, sonder das mich treybt on allen mein willen und zuthun, das treybt mich, die schrifft zu lesen umb zeügknuß willen.” Denck II.21.16-21. "Wer den gayst nit hatt und in in der schrifft zu finden sich vermißt, der suchet liecht und findt finsternuß, suchet leben und findet eyttel todt, nitt allain im alten testament, sonder auch im newen."

5. J. Denny Weaver, "The Work of Christ: On the Difficulty of Identifying an Anabaptist Perspective”, MennQR (1985), 107-29. Denck afviser at Gud har brug for et sonoffer, men understreger dog nødvendigheden af Kristi død og opstandelse i sin Wiederruffra 1527.

6. James Beck, "The Anabaptists and the Jews: The Case og Hätzer, Denck and the Worms Prophets”. MennQR 75 (Goshen: Mennonite Historical Society 2001), 407-428.

7. Se Packull 1977, 40-44; Morwenna Ludlow, "Why Was Hans Denck Thought To Be a Universalist?”, JEH 2 (Cambridge: Cambridge University Press 2004), 257274.

8. Kellers og Kristofer Jansons biografier har nærmest karakter af hagiografi. Ludwig Keller, Ein Apostel der Wiedertäufer (Leipzig: S. Hirzel 1882); Kristofer Janson, Et glemt Sandhedsvidne (Johan Denck) (Kristiania: B. Omtvedts forlag: 1897); Alfred Coutts, Hans Denck, 1495-1527: Humanistic and Heretic. (Michigan: Macniven \& Wallace 1927); Rufus M. Jones, Spiritual Reformers in the 16th and 17th Centuries. (London: Macmillan \& Co. 1914). 
anti-humanistisk (Bauman 1991, 25). Karakteristikken nedenfor er på linje med Bauman.

Der er foreslået mange mulige kilder til Dencks tænkning; Erasmus havde $\mathrm{fx}$ i almindelighed en vis betydning for døberbevægelserne, som trods forskellige udspring (polygenesis) delte Erasmus' forståelse af missionsbefalingen som en treleddet befaling om at undervise, gøre disciple og til sidst at døbe. ${ }^{9}$ Også en mulig jødisk indflydelse er blevet nævnt: Selvom Denck og Hätzer ikke nævner nogen kilde, fik de til oversættelsen af profetbøgerne sandsynligvis hjælp af lokale jøder i Worms. ${ }^{10}$ Trods overordnet tilfredshed kritiserede Luther oversættelsens jødiskhed. Hätzer forsvarede før sin henrettelse en klar antitrinitarisk teologi, hvad ikke var tilfældet for Denck. Dencks vistnok positive relationer til jøderne i Worms viser dog et vist økumenisk potentiale i hans spiritualisme: Enhver profet, som fører til Israels ene Gud, peger på samme sandhed, uanset hvor fremmedartet hans tale forekommer at være, bemærker Denck. ${ }^{11}$

Ikke uden grund er Denck blevet kaldt "den økumeniske gendøber" (Packull 1977). I sin Wer die Wahrheit wahrlich lieb hat fra 1526 forklarer Denck, hvordan alverdens sekter er opstået, fordi hver især baserer sine doktriner på udvalgte skriftsteder uden at tage modstridende skriftsteder i betragtning. Men sandheden kan kun findes ved at forene modsætninger. ${ }^{12}$ Den ene indeholdes i den anden, som det mindre i det større, tid i evighed, endelighed i uendelighed og så videre. Denck lægger sig derved i en tradition for paradokstænkning, som kan spores tilbage til i hvert fald Pseudo-Dionysius, Eckhart, Cusa, Tauler med videre, og som kan genfindes i fx Sebastian Francks Paradoxa fra 1534. Denck oplister fyrre par af tilsyneladende modsigende skriftsteder, såsom "jordens porte var for evigt slået i bag mig” (Jon 2,7) og "Så sagde Herren til fisken, at den skulle kaste Jonas op på landjorden" (Jon 2,11). ${ }^{13}$ Dencks pointe synes at være, at tænkningen så at sige må opløses indefra, og at paradokser ved at gøre dette peger og henviser ("weyset und deüttet") til Gud..$^{14}$ Versene fra Jonasbogen

9. Deppermann, Klaus, "From Monogenesis to Polygenesis: the historical discussion of Anabaptist origins" i MennQR 49 (1975), 83-121; Weaver 2005, 22; se Denck II.83.11-13.

10. Beck (2001), 410; 422-424.

11. Denck II.65.33.

12. Denck II.68.14: “Zwu gegenschrifft müssen bayde war sein.”; Denck II.58.1821: "Wer die flaischlich wahrhait annympt und des gaysts warhait übersehen will, das ist, welcher zway widerspil in der schrifft nitt auff ain gleych wag legt, welches er auß den zwayen nympt, so hat er doch nun ain halbe warhait.”

13. Denck II.69.5-7; II.72.23-25.

14. Denck II.74. 
peger derudover på, at fortabelse og frelse ikke egentlig er modsætninger, men at fortabelse er indeholdt som led i frelsen.

Denne tankegang kan genkendes fra et lille skrift kaldet Deutsche Theologie, Dencks nok vigtigste inspirationskilde, som i arven fra den tyske mystik i letfattelig form forklarer en række åndelige temaer. ${ }^{15}$ Deutsche Theologie er af nyplatonsk støbning (Gud er det Ene, etc.), men der findes samtidig en klar distinktion mellem Gud og den skabte natur. ${ }^{16}$ Menneskets viljesudøvelse er af naturen modsat Gud og derfor også uundgåeligt syndig. Det menneskelige selv må derfor dø, for des mere selv, mit, mig, jeg og så videre, des mere plads er der til Guds jeg. ${ }^{17}$ Mennesket er ligesom Kristus derfor nødt til at nedstige til helvedet for at kunne opstige til himlen. Der er tale om et klart resignatio ad infernum-motiv: Når et menneske i erkendelsen af sin synd bringes til en tilstand, hvor der intet ønske eller håb er tilbage om frelse, finder omvendelsen sted. Både helvede og himmel er derfor sikre tilstande, som mennesket dog ikke selv er herre over, men som kommer og går. ${ }^{18}$ Det farlige er ikke "det helvede, som fører til himlen”, men den optagethed af skabningen, som fører til glemsel. Denne tanke om den åndelige krise som nødvendig forudsætning for frelsen udfoldes hos Denck, som vi skal se nedenfor.

\section{Gud og mennesket}

Som i Deutsche theologie er Gud og mennesket for Denck ikke bare radikalt forskellige, men modsætninger. Hvad der for mennesket er intet, er for Gud noget, og hvad der for mennesket er noget, er for Gud intet ("etwas vor Gott nichts ist"). ${ }^{19}$ Dencks ontologi er dialektisk, for så vidt Denck forstår virkeligheden som bestående af mod-

15. Luther, som i 1518 stod for en udgivelse deraf, rangerer i forordet Deutsche Theologie sammen med Bibelen og Augustin. Deutsche Theologies oprindelse er $u k e n d t$, men den findes $i$ otte manuskripter fra det 15. ärhundrede. Luther synes at have mistet interessen for bogen, men den fik senere indflydelse på pietismen gennem Jakob Spener. Eyn Deutsch Theologia, etc. (Wittenberg 1518); Bernard McGinn, The Harvest of Mysticism (New York: The Crossroad Pub. Co. 2005) 393.

16. Deut. Theol. $\$ 27 ; \$ 40 ; \$ 42$ Patristisk teologi, især af den græske type, deler en vis fællesmængde negativ teologi med nyplatonismen, men hvor denne i kristendommen er udtryk for et radikalt skel mellem skaber og skabning er dette ikke tilfældet i nyplatonismen, som er grundlæggende panteistisk eller panenteistisk. Mortley 1986; Johannes Aakjær Steenbuch, Doing the Unthinkable (Ph.d.-afhandling 2014).

17. Deut. Theol. $\$ 16$.

18. Deut. Theol. $\$ 11$.

19. Denck II.33.20-24. 
sætninger, der er defineret ved hinandens gensidige negation. Dencks ontologi er ikke (blot) dualistisk, for modsætningernes værdi kan netop udskiftes i denne gensidige negation: Mennesket kan blive det, der for Gud er noget, ved at blive det, der for mennesket er intet hvilket igen er muligt, fordi Gud i Kristus er blevet det, der for Gud er intet. Der synes at være tale om en funktionelt bestemt ontologi, som betyder, at noget kan være både intet (nichts) og noget (etwas) på én gang, alt efter perspektiv og funktion. Denck udfolder dog sjældent dette på systematisk vis, men typisk i relation til fx spørgsmål om synd og viljens frihed. ${ }^{20}$

Dencks syndsbegreb er tættere knyttet til denne bestemmelse af menneskets natur end til et moralsk forhold og må således forstås som en ontologisk bestemmelse. En moralsk og eventuel epistemologisk forståelse af synden bør forstås på baggrund af dette. Synd er menneskets forsøg på selv at opnå retfærdighed i ulydighed og vantro ("ungehorsam und unglaub"), jf. Joh 17, skriver Denck. ${ }^{21}$ Synd er intet andet end udøvelsen af menneskets egen vilje, det, som for mennesket er muligt. For kødelige mennesker er kun synd muligt, alt godt er umuligt. Synd bestemmes så at sige dialektisk-modalt: Synd er det for Gud umulige, men for mennesket mulige, mens det gode er det for Gud mulige og for mennesket umulige. Synd er intet over for Gud, og at intet er umuligt for Gud, synes netop at skulle forstås sådan, at intet, altså synd og ondskab, er en umulighed for Gud, da disse er defineret som Guds modsætning. ${ }^{22}$

Der er ikke tale om et rent symmetrisk forhold mellem menneskets natur og Gud, sådan at Guds vilje retter sig mod mennesket og menneskets mod Gud. Guds vilje og menneskets vilje adskiller sig derved, at Gud i modsætning til mennesket af natur ikke søger sig selv - ikke bare er Gud kærlighed, men sand kærlighed er Gud selv ("die lieb ist Gott selb"), som gladelig bliver intet ("gern nichts sein wolte") for andres (menneskets) skyld. ${ }^{23}$

Mennesket har ikke nogen naturlig længsel efter eller kærlighed til Gud, men kun til sig selv, og da kun Gud er god, kan mennesket ikke af sig selv gøre godt, skriver Denck i Ordnung Gottes: "De er altid to, Gud og mennesket, og da de er to, så gør hver enkelt sit, godt og ondt, hver enkelt ifølge sin art." ${ }^{24}$ Her må man i øvrigt spørge, om Bauman gør ret i at indsætte "[will]" i sin engelske oversættelse ("each

20. Se dog især Denck II.29.6; II.34.30-35.3; II.60.15.

21. Denck II.91.24-27.

22. Fx Denck II.29.37.

23. Denck II.33.3; Denck II.64.7; II.77.10-15.

24. Denck II.94.15: "Es seind je zwey, Gott und der mensch, und so sie zwey seind, so thut eyn jedliches das sein, guts und böß, eyn jedlichs nach seiner art." 
does his own [will] inherently"): Der er for Denck ikke blot tale om, at mennesket gør sit eget, når det aktivt udøver sin vilje, men også når mennesket af sig selv vælger at være passiv. Både menneskets aktive gøren (thun) og dets laden stå til (lassen) er intet over for Gud og derfor synd, så længe det kommer fra mennesket selv. ${ }^{25}$

Erkendelsen af, at mennesket af natur (medfødt set) ikke kan gøre noget godt, er udgangspunktet for Dencks Nüremberg-bekendelse: "Jeg, Hans Denck, bekender, at jeg i sandhed fornemmer, føler og mærker, at jeg medfødt set (angeborner weyß) er et arme menneske, som er underkastet al sygdom i krop og legeme (der aller kranckheyt leybs und der seelen underworffen ist)." ${ }^{26}$ Langt snarere end at være en humanist med tiltro til den menneskelige naturs iboende godhed er Denck således klart bevidst om, at synd er et ontologisk vilkår for mennesket. Det er derfor ikke korrekt, når Packull skriver, at Denck ikke havde et radikalt syndsbegreb (Packull 1977, 58). Når Denck i sin bekendelse skriver, at han også fornemmer noget andet i sig, som kæmper mod hans medfødte ondskab, er det ikke (som Packull ellers beskriver det) en medfødt eller naturlig egenskab, der som hos mystikerne ikke er gået tabt ved syndefaldet, men Guds dømmende Ord, som søger at overkomme mørke og vantro for at bane vej for Kristi retfærdighed. Men, skriver Denck: "Das ist in mir noch nit." ${ }^{27}$

Det er netop denne kamp mellem menneskets vilje og Guds vilje, som er central for Dencks begreb om eftergivenhed, som diskuteres nedenfor.

\section{Eftergivenhedens dialektik}

Dencks identifikation af ondskab med ikke-væren medfører en kritik af vulgærdeterminismens påstand om, at Gud, fordi han har skabt alt og er i alt, også udvirker synden. Gud er rigtig nok i alt, skriver Denck, men da synd er intet, kan Gud ikke være til stede i synd eller være årsag dertil. Gud har imidlertid tilladt synd, for at mennesket, idet det synder, kan lære, at det ikke besidder retfærdighed i sig selv, forklarer Denck i sin korte afhandling om, hvorvidt Gud er årsag til det onde. ${ }^{28}$ Syndserkendelse er, så at sige, det bedste middel mod menneskers selvretfærdighed, men for at der kan være syndserkendelse, må der først være synd (dette skal næppe forstås ontologisk, sådan at

\footnotetext{
25. Denck II.34.30-35.3; II.60.15.

26. Denck II.20.5-7.

27. Denck II.22.3.

28. Denck II.29.4-5.
} 
det onde er en forudsætning for det gode, men kun erkendelsesmæssigt). Gud er barmhjertig, men barmhjertighed er kun barmhjertighed, når der faktisk er noget at forbarme sig over, skriver Denck med henvisning til Rom 11,32. ${ }^{29}$ Gud har derfor skabt mennesket med dets egen vilje og friheden til at synde - men vel at mærke kun fordi Gud i sin almagt vidste, at han var i stand til at overkomme synden. ${ }^{30}$

I sin naturlige tilstand er mennesket underlagt løgnen om, at det til forskel fra resten af skabningen mangler noget, fx forstand, vilje eller styrke: At mennesket intet er og derfor må handle på egen hånd for at blive noget. ${ }^{31}$ Menneskets vilje søger i modsætning til Gud kun sit eget. ${ }^{32}$ Men netop derved bliver mennesket intet (for Gud). Hvad der for mennesket er skabelse (machen), er for Gud at bryde ned (brechen), og omvendt. Derfor er alt godt (det, der er noget for Gud) umuligt for mennesket, når det vil være noget i egen kraft. Des mere et menneske ønsker at være noget, det ikke er, des mere er Gud mod dette menneske, skønt Gud aldrig er mod noget, skriver Denck (Gud er kun mod intet, dvs. synd)..$^{33}$

Den adskillelse, der sker mellem Gud og mennesket, når det med sin viljesudøvelse vil være noget og derfor bliver intet, og altså synder, synes for Denck i sig selv at være Guds straf for synd. ${ }^{34}$ Hvis mennesket gjorde noget (etwas), ville det ikke fortjene straf, men da det gør intet, må det finde sig i den straf, som dette intet bærer i sig selv. ${ }^{35}$ Som ondskab er synd over for Gud intet (nichts vor Gott), men som et middel til revselse er synd godt, og for så vidt det er godt, er det noget (Wie sy aber gut ist, so ist sy etwas). ${ }^{36}$ Menneskets synd er intet for Gud, men som en skolelærer for at belære straffer sine elever når de intet laver, straffer Gud mennesket, når det intet gør - altså når det gør synden, som for Gud er intet, skriver Denck. ${ }^{37}$ Formålet er at nedbryde menneskets selv, så dets vilje kan udskiftes med Guds. I Was geredt sei, daß die Schrift sagt, skriver Denck:

Ja, fordi blod og kød er så modsat Gud, at vores handlen for Gud er en laden stå til, vores gøren en bryden ned, og vores noget for Gud intet, så

29. Denck II.29.17.

30. Denck II.29.14.

31. Denck II.53.33-35: "Wer ain besondern oder andern verstand, will oder krafft haben [will] wider Gottes will, der mag wol wenen, er hab, das er doch in der warhait nit hatt, und gedunckt in, er mangle, des alle creatur vol ist."

32. Denck II.33.3.

33. Denck II.54.1-10.

34. Denck II.94.18-25.

35. Denck II.30.1-6.

36. Denck II.29.25-30.

37. Denck II.29.37. 
burde vi altid høre, hvad ånden har at sige os: At Guds bryden ned, som viser sig for os, er den bedste gøren, og at Guds Intet (som vi ikke kan erkende) er det højeste og ædleste Noget. ${ }^{38}$

Det er her det centrale begreb om eftergivenhed (gelassenheit) ${ }^{39}$ har sin plads. Når mennesket vil være noget, gør det intet, altså synden, og kun ved at blive intet i eftergivenhed kan det faktisk gøre noget. Guds dom er nødvendig for at bringe mennesket til eftergivenhed, for kødet kan ikke forstå, hvad Gud siger, med mindre det først er blevet ydmyget (wa es nit zuvor gedemüttigt ist). ${ }^{40}$

At blive intet (for mennesket) i eftergivenhed er at lægge illusionen om, at mennesket er nødt til at handle på egen hånd og skabe sig selv for at være noget (for sig selv) fra sig, for netop derved at kunne være noget (for Gud). ${ }^{41}$ Mennesket må bringes til en tilstand af håbløshed, hvor dets egen-vilje helt tilintetgøres. Dette er Kristi gerning. Traditionelt er Kristi embeder blevet inddelt i tre,${ }^{42}$ men hos Denck reduceres de til to: Lov og evangelium. Begge er sider af Guds retfærdighed:

Retfærdigheden virker gennem ordet, som var fra begyndelsen, og som derpå er opdelt i to, lov og evangelium, som følge af de to embeder, som Kristus som retfærdighedens konge øver, nemlig at døde de vantro og at levendegøre de troende. ${ }^{43}$

Denck tilføjer, med henvisning til 1 Sam 2,6, at da alle troende engang har været vantro, måtte de først $\mathrm{d} ø$ for at blive vakt til live. Kristi to embeder er med andre ord at føre ned i helvede og op igen (jf. resignatio ad infernum-motivet fra Deutsche Theologie). Den gudløse er forudbestemt til helvedes smerte, men kun for at han derved kan opnå en erkendelse af sin elendighed, så han kan anråbe Gud

38. Denck II.33.15-24: "Ja, dieweyl blut und flaisch Gott also widerspennig ist, also, das unnser thun vor Gott ain lassen, unnser machen vor Gott ain brechen, unnser etwas vor Gott nichts ist, so solten wir ye hören, das der gaist in unns saget: Das Gottes brechen, wie es unns ansihet, das beste machen ist, und das Nichts Gottes (welchs unns nicht gedunckt) das höhist und edlest Etwas were."

39. Begrebet kendes i øvrigt fra Heidegger, som låner det fra Eckhart. Fx Martin Heidegger, Gelassenheit (Stuttgart: Klett-Cotta 2004).

40. Denck II.65.14.

41. Denck II.54.3-5.

42. Det profetiske, det præstelige og det kongelige. Fx Eusebius Ecc. His. I.3.8.9; Calvin Institutes II.15.

43. Denck II.23.3-6: "Die gerechtigkayt würckt durch das wort, das von anfang war, und wirt darum in zway getaylet, gesetz und evangeli, von zwayer ambt wegen, so do Christus ein konig der gerechtigkayt übet, nemlich zu tödten die unglaubigen und lebendig zu machen die glaubigen.” 
om hjælp - som derved kan forbarme sig over alle, skriver Denck med henvisning til bl.a. Rom $11 .{ }^{44}$ Det er med dette formål, at Guds retfærdighed nedbryder vantro og synd gennem loven, hvorefter evangeliet straks træder til og fører til tro. ${ }^{45}$ Loven er, lader det til, simpelthen identisk med de indbyggede konsekvenser af menneskets synd, som ender med at nedbryde mennesket. For så vidt man kan tale om en naturlig lov, er denne rent negativ, dvs. den har til formål at nedbryde mennesket med dom. ${ }^{46}$

Denck blev af Nürenberg-byrådet kritiseret for, at hans forståelse af loven strider mod Paulus, for hvem loven ikke formår at nedbryde vantro. ${ }^{47}$ I dette synes dog at mangle en forstålse af, hvad det for Denck betyder, at lov og evangelium er to sider af Guds Ord, Kristus selv, og derfor uadskillelige. ${ }^{48}$ Det er netop kun i Kristus, at lov og evangelium er to sider af samme sag. Af samme grund kan Denck skrive at hele loven er ophævet (auffgehaben) for den, som har kærligheden til Gud skrevet i sit hjerte. ${ }^{49}$ Dette betyder dog næppe, at den er tilsidesat, men snarere, at den er indeholdt eller opslugt i en større helhed..$^{50}$ Men det er netop i Kristus, at loven ophæves, altså opsluges i en større helhed. Loven er i denne forstand alligevel ikke rent negativ, men indeholder i sig (eller peger ud over sig selv på) sin modsætning, evangeliet.

Skal man tro Bauman, er Kristus for Denck simpelthen identisk med eftergivenhed (Bauman 1991, 25-27). Det er rigtigt, at både Kristus og eftergivenhed omtales som midlet mellem Gud og mennesker, men måske det er mere præcist at bestemme eftergivenhed som

44. Denck II.92.10-17: "Alßbald der gotloß also sagt, so ist er an der stat, darzu er verordnet ist, das ist die hell, Proverb. 9, Psalm 115. Nit das er da bleiben wölle oder müß, Psalm 77; dann auch die hell vor dem herrn bloß ist, und das verdammnuß hat keyn decken, Job 26; doch uber seinem starcken arm nit, dann in der höchsten gerechtigkeyt, das ist, das wir zorn nennen, damit er unns der hellen schmertzen aufflegt, Psalm 18, und gibt unß unser elend selbs zu erkennen, auff das wir in der nott zu im schreien, und er unnß helffe, Hos. 9; das ist, das Paulus sagt, Rom.11: Gott hats alls underm unglauben beschlossen, auff das er sich aller erbarme!” Det er især en passage som denne der har givet Denck ry for frelsesuniversalisme.

45. Denck II.22.30-32.

46. Fx Denck II.34.4-5.

47. Gutachten der Nürnberger Prediger $\$ 5$.

48. Denck II.23.3-6.

49. Denck II.63.7-9.

50. Den jødiske indflydelse på Dencks tænkning afspejles (måske) i hans positive syn på loven. Beck (2001). Det kan være rigtigt nok, at forholdet mellem lov og evangelium hos Denck kun på overfladen svarer til en luthersk dialektik mellem disse (Packull). Sondringen går ikke mellem Det gamle og Det nye Testamente, men gennem hele Skriften, som i det ydre er lov, men som tegn peger ud over sig selv på evangeliet. Packull (1977), 58. 
funktion af momentet mellem Kristi to embeder, lov og evangelium, hvor omvendelsen finder sted. Det er på den ene side menneskets egen synd og ondskab, der bringer det til en tilstand af fortvivlelse, men for så vidt disse er redskaber for Gud, er der på den anden side tale om Guds gerning, i hvert fald hvad angår menneskets erkendelse deraf (igen en funktionel bestemmelse). Det er Guds Ord, som gør det klart, at mennesket selv har påført sig sine lidelser og at den af mennesket skabte afstand til Gud, som for Gud er intet, men for mennesket er noget, bærer straffen i sig selv. At synden intet er, forstås dog først, når mennesket "overgiver sig til Gud og bliver intet, selvom han dog er skabt af Gud." ${ }^{51}$ Først efter at et menneske har gennemgået det helvede, som det tror, Gud påfører det, men som det egentlig har påført sig selv, står det klart, at Gud har været nådig fra begyndelsen, og at mennesket selv har påført sig straffen for sin synd..$^{2}$

Spørgsmålet er i det følgende hvor meget mennesket selv kan gøre til eller fra i denne proces - hvad er relevant for så vidt vi ønsker at vurdere Dencks angivelige "humanisme", som i karakteristikker af Denck ofte forbindes med "synergisme".

\section{Retfærdiggørelse og frelse}

Dencks forkærlighed for paradokser kommer til udtryk i hans diskussion af menneskeviljens frihed. I debatten mellem Erasmus og Luther lader der umiddelbart til at være to muligheder: At mennesket enten er frit eller ufrit over for Gud. Begge påstande er i sig selv sande, skriver Denck, men begge er samtidig falske, fordi de taler om mennesket alene ud fra mennesket selv. Nogle siger, at de har fri vilje, men gør ikke Guds vilje, andre, at de ingen fri vilje har, da de er klar over, at de ikke kan gøre det rigtige, skriver Denck. ${ }^{53}$ Den første påstand er udtryk for forfængelighed, mens den anden er udtryk for falsk ydmyghed. Begge dele kommer fra menneskets egen selv-søgende natur. Men sandheden om menneskeviljens frihed findes i et tredje punkt, nemlig i ophævelsen af menneskets egen vilje (fri eller ej) i eftergiven-

51. Denck II.30.1-6: "Wie aber die sünd nichts sey, mag wol vernomen werden von dem, der sich Gott übergibt und nichts wirt, so er doch von Gott etwas geschaffen ist. Ditz wirt ain yeder versteen nach der maß seiner gelassenhait, wie auch alle rede Gottes gehört müssen werden.”

52. "Gott ist von anbeginn gütig, das erkennen und vertrawen wir im erst nach aller betrübnuß." Denck II.93.28-29.

53. Denck II.96.23-97.2. 
hed, og det gør derfor ingen forskel, om vi kalder menneskets vilje fri eller trælbunden, skriver Denck. ${ }^{54}$

Denck ville derfor næppe uden videre være enig i, at "mennesker frelses eller fortabes idet de siger $j a$ eller nej til et indre Lys eller Ord" (Rufus Jones)..$^{55}$ Langt snarere sker frelsen, idet mennesket opgiver sin egenvilje og derved ophører med at sige nej, hvilket ikke er det samme som aktivt at sige ja med egenviljen i behold. Når Denck kaldes humanist, er det ofte, fordi hans opfattelse af viljens frihed bliver sammenlignet med Erasmus, men dette er altså næppe rimeligt. Det er nok mere sandsynligt, at Denck har fået sin opfattelse af viljens frihed fra Deutsche Theologie end fra Erasmus, hvis position Denck opfattede som ligeså forkert som den lutherske determinisme og prædestinationslære. Selvom Gud ikke ligefrem tvinger mennesker til noget, er det ifølge Deutsche Theologie ikke i menneskets magt at bringe sig selv til den fortvivlelse, som fører til selvfornægtelse, lydighed og efterfølgelse af Kristus. ${ }^{56}$ Det er Gud, der bringer menneskets vilje til intet og udsletter dets vantro.

Det samme synes at gælde for Denck, som efter at have beskrevet sig selv som vantro i sin Nürenberg-bekendelse skriver: "Hvor klart jeg ser, at min vantro ikke kan bestå for ham.. ${ }^{57}$ Der er ikke tale om nogen frelsesvished, men om en fortløbende kamp, hvor mennesket igen og igen mister sig selv gennem troens lydighed..$^{58}$ Denne kamp skal dog næppe forstås som menneskeviljens kamp med sig selv. At menneskets aktive gøren (thun) er intet over for Gud, betyder ikke, at menneskets passivitet eller laden stå til (lassen) er mindre syndefuldt, så længe det kommer fra mennesket selv. Begge er ekstremer i mellem hvilke midten (mittel) er "sandhedens ord". ${ }^{99}$ For falske kristne er al gøren og laden stå til, selv det mest funklende intet andet end mørke (finsternuß). ${ }^{60}$ Laden stå til (lassen) er ikke det samme som eftergivenhed (gelassenheit). Det betyder, at asketiske øvelser o.l. også

54. Denck II.107.24-25.

55. Jones (1914), 17-30. Nakano har påpeget at Jones i sin læsning af kvækerteologen Robert Barclay (1648-1690) udskifter begreber om selvfornægtelse med en liberal-humanistisk forestilling om menneskelig selvudfoldelse. Der er flere ligheder mellem Denck og Barclays begreber om eftergivenhed og intethed (nothingness). Nakanos kritik af Jones kan overordnet set appliceres på Jones’ læsning af Denck. Yasuharu Nakano, Self and Other in the theology of Robert Barclay, Ph.D.-afhandling (Birmingham: Ikke udgivet 2011).

56. Deut. Theol. \$33; $\$ 11$.

57. Denck II.21.23: "Wiewol ich sihe, das mein unglaub vor im nit besteen kan." 58. Denck II.91.13-14: "Der kampff ist, daß der mensch sich selbs gern verlieren wil und imerzu durch den gehorsam des glaubens verleuret, auff das er das böß, das er in ime befindet, uberwinde, Röm. 7,1. Cor. 9.”

59. Denck II.34.30-35.3.

60. Denck II.60.15. 
er (eller kan være) udtryk for synd. Mennesket kan derfor ikke uden videre beslutte sig for at blive helligt eller at elske Gud i stedet for sig selv. Eftergivenhed handler ikke som i en destruktiv nihilisme om at ville intet, men om ikke at ville noget. Mennesket kan ikke med sin egen vilje nedbryde sig selv, men må vente på, at Gud nedbryder dets vilje, for derefter at føre sin vilje igennem (da det er Guds opgave at bringe til syndserkendelse, kan tugtelse for Denck i øvrigt næppe være menneskers opgave, selvom Gud kan bruge fx øvrigheden til dette formål). Det er Gud selv, der placerer mennesket i det dybeste helvede, som fører det til den åndelige fattigdom, som er nødvendig for at etablere eftergivenhed. ${ }^{61}$

Mennesket må altså bringes til eftergivenhed. At kende Gud er kun muligt for den, der følger Kristus - men at følge Kristus er omvendt, ifølge Denck, kun muligt for den, der allerede kender Gud. For mennesket er dette altså umuligt, medmindre Gud dømmer og åbenbarer sig for mennesket og med sit ord frisætter det til at handle aktivt $\mathrm{i}$ synd eller til at give efter: "Så snart et menneske bliver bevidst om ordet, er han igen fri til at fortsætte i sin ondskab, eller at opgive sig selv i lidelse." ${ }^{62}$ Mennesket er ikke frit til af sig selv at vælge det gode eller det onde, men i det øjeblik, det bliver bevidst om Guds dom, sættes det fri til at holde fast i sin egenvilje eller i eftergivenhed at overgive sig til Guds vilje. Mennesket er altså kun egentlig frit i den af Guds dom fremkaldte krise. Frihed er at i eftergivenhed at være fri af sin egenvilje, og der at kunne lade Guds vilje tage over.

Mennesket vedbliver dog at være frit til at søge at føre sin egen vilje igennem. Men forsøger mennesket at løbe ind i himlen ved egen kraft, ender det i det modsatte, skriver Denck. Vil man løbe, må man løbe passivt (leydenderweyß), altså lade Gud gøre arbejdet. ${ }^{63}$ Det er ulydighed, usandhed og ufrihed at løbe enten langsommere eller hurtigere, end Gud giver kraft til. ${ }^{64}$ En selvpåført hellighed og kærlighed er falsk, skriver Denck, for det er ikke muligt at elske umedieret af Guds sandhed og kærlighed, altså af Kristus selv, som bringer mennesket til eftergivenhed. ${ }^{65}$ Forsøger et menneske uden Guds åbenbaring at gøre det arbejde, som hører til Guds Ånd, perverteres nåden, skri-

61. Denck II.93.7.9: "Da hebet sich an die seligkeyt, eh das wir sein gwar werden, wenn unnß der herr am allertieffsten in der abgrund der hellen setzt, daß wir also armgeystig werden, Mat. 5, daß wir weenen, wir müssen in unß selbs vergeen.”

62. Denck II.92.23.

63. Denck II.32.30-35.

64. Denck II.107.14-16.

65. Denck II.82.29-31. 
ver Denck, som forklarer, at det netop var det, der førte til kætterier og splittelser i kirken allerede efter apostlenes død. ${ }^{66}$

Det er således næppe korrekt, som Packull gør det, at tale om et aktivt samarbejde (cooperatio) mellem Guds og menneskets vilje. Denck kan næppe kaldes moralist eller synergist, selvom der ingen tvivl er om, at den faktiske moralske transformation af mennesket er centralt for Denck, for hvem kristendom snarere handler om at være Kristi discipel end at tilslutte sig bestemte trossætninger. Men den transformation kan kun være Guds gerning. Mennesket kan intet godt gøre, men må lade Gud gøre sin gerning i sig. ${ }^{67}$ Derved sker en indre faktisk retfærdiggørelse, som resulterer i handlinger i det ydre. En rent forensisk forståelse af Guds nåde uden en indre transformation er grundlæggende hedensk, hævder Denck. Retfærdiggørelse indebærer en faktisk forandring i mennesket, som guddommeliggøres (vergottet), idet Gud menneskeliggøres (vermenscht), men altså netop kun derved (guddommeliggørelse betyder simpelthen, at menneskets vilje udskiftes med Guds). ${ }^{68}$

Der er ifølge Packull for Denck tale om iustitia propria snarere end iustitia aliensis (Packull 1977, 61), men måske er det mere korrekt at tale om en aliensis et propria, for så vidt retfærdiggørelsen er Guds gerning, som dog sker i menneskets indre. Der er på ingen måde tale om, at mennesket retfærdiggøres og frelses af sine egne gerninger. Fortabelsen er netop at søge retfærdiggørelse af sig selv uden eftergivenhed:

Det perverterede menneske, som søger sig selv, men ikke vil miste sig selv, og derfor i evighed måske ikke finder sig selv, vil handle og sejre, før han har lidt; vil tro, før han ved, hvad tro er; vil være salig uden at vide noget om fortabelse; vil leve uden at vide, hvad døden er. ${ }^{69}$

Den egentlige fortabelse er ikke at ville frelses uden fortabelse, at saliggøres uden middel (on mittel selig werden), dvs. den af Kristus påførte eftergivenhed, og altså at frelses ved egen hjælp og vilje. Mennesket omvender i så fald Guds vilje, som til gengæld omvender menneskets vilje og giver det forbandelse i stedet for den salighed, det

66. Denck II.22.7-13.

67. Denck II.31.26-27.

68. Denck II.25.18-19; II.31.26-27.

69. Denck II.96.18-23: "Der verkert mensch, der sich selbs sucht, aber nit verlieren wil, und doch in ewigkeyt nit finden mah, der wil thun und uberwinden, eh $\mathrm{da}$ er gelidten hat; wil glauben, eh er weyß, was glauben ist; wil selig sein, weyß von keyner verdamnuß; wil leben, weyß nit, was der todt ist." 
begærer. ${ }^{70}$ Fortabelse er at holde fast i sin egenvilje og egenkærlighed, hvilket mennesket i nogen grad er frit til. Lytter vi ikke til Guds ord i vores hjerter, virker det til vores fordømmelse, bevidst eller ubevidst, men denne fordømmelse er netop også hvad der bringer mennesket til eftergivenhed. ${ }^{71}$

Spørgsmålet er så om Denck var frelsesuniversalist, som flere har hævdet. Denck forsvarede ikke frelsesuniversalisme eksplicit på skrift, men der er flere passager, som peger i den retning, samt en række vidnesbyrd, bl.a. fra Urbanus Rhegius, som rapporterede, at Denck under et forhør brød grædende sammen og indrømmede, at han ikke kunne forestille sig en endeløs straf. Ifølge Ludlow var anklagerne mod Denck dog sandsynligvis fabrikerede for at associere ham med origenisme (Ludlow 2004, 258). Hvis vi skal tro Ludlow, kan Dencks teologi derfor ikke uden videre kategoriseres som frelsesuniversalisme, selvom han forsvarede universaliteten af Kristi forsonende gerning. Forsoningsuniversalisme er kun ensbetydende med frelsesuniversalisme, hvis man i øvrigt forudsætter en augustinsk-reformatorisk prædestinationslære, hvor menneskets vilje så at sige ikke er fri til at kile sig ind mellem forsoning og frelse (Ludlow 2004, 274).

Spørgsmålet er dog, hvor meget menneskets vilje egentlig betyder, når den først er blevet nedbrudt af Guds dom, skal vi tro Denck. At Gud i det dybeste helvede frisætter mennesket til at handle enten ud fra sin egen eller Guds vilje, synes sjældent for Denck at være et forhold af eskatologisk betydning, men et spørgsmål om afgørelse i det øjeblik, hvor mennesket bliver klar over sin tilstand af fortabelse. At mennesket er frit til igen og igen at afvise Guds vilje udelukker i hvert fald ikke, at Gud i sidste ende får sin vilje: Menneskets frelse. ${ }^{72}$

70. Denck II.34.16-17.

71. Denck II.95.8-14.

72. For mere om Dencks tendens til frelsesuniversalisme, se Max Schär, Das Nachleben des Origenes im Zeitalten des Humanismus (Basle-Stuttgart: Afhandling 1979), 297; George Huntston Williams, The radical Reformation (London: Weidenfeld and Nicolson 1962), 832-45. Det kan undre, at Denck-receptionen i spørgsmålet om menneskets vilje har bevæget sig fra en humanistisk læsning til en mere anti-humanistisk, mens den parallelt har bevæget sig fra en overvejende frelsesuniversalistisk til en mere afmålt læsning. Man kan selvfølgelig hævde, at humanismens positive menneskesyn ansporer til en optimistisk eskatologi. Men samtidig er det netop troen på menneskets fri vilje, som typisk kendetegner humanisme, der gør frelsesuniversalismen mindre utvetydig. 


\section{Slutkarakteristik}

Selvom der ikke er meget decideret negativ teologi hos Denck er det af central betydning, når han skriver, at Guds intet for mennesket er ubegribeligt (citeret ovenfor). Fordi alt menneskeligt må udslettes og blive til intet i eftergivenhed, er Guds åbenbaring før-intellektuel. Dencks radikale skelnen mellem Gud og mennesket indebærer således en spiritualisme, hvor Gud åbenbarer sig uden ydre mediation, og hvor sandheden ikke kan erkendes positivt ved det skabte, men kun ved sandheden, Gud selv. ${ }^{73}$

En spiritualisme som denne bør dog skelnes fra mysticisme, som vi kender den fra fx Eckhart. Goertz forstår "augustinsk spiritualisme" semiotisk som en adskillelse af tegnet (menneskelige, typisk udvortes, former) og det betegnede (Guds And), mens Packull og Born definerer spiritualisme som en skarp adskillelse af Gud og mennesker, som kun kan overvindes af Guds Ånd. Mysticisme antager derimod en indre lighed og derfor en kontinuitet mellem Gud og mennesker, som ikke er gået tabt i syndefaldet og derfor kan tjene som anknytningspunkt. ${ }^{74}$ Med denne skelnen må Holls karakteristisk af døberbevægelsen som grundlæggende mysticistisk nuanceres eller afvises (hvad den da også er blevet med henvisning til især de schweiziske døberes biblicisme). ${ }^{75}$

Dencks spiritualisme kom til udtryk i hans syn på edsaflæggelse, magtanvendelse, ekskommunikation (bann) og ikke mindst dåb. ${ }^{76}$ Disse spørgsmål var afgørende for mange af døberbevægelserne, men for Denck havde de kun relativ betydning, da alle (med undtagelse af magtanvendelse, som for Denck strider åbenlyst mod Jesu eksempel, og derfor altid er et udtryk for selvhævdelse) må forstås efter hvorvidt de er udtryk for selvhævdelse eller selvfornægtelse og kærlighed. ${ }^{77}$ Hvor der er fare for det første, er det bedst helt at undvære ydre former, skriver Denck. I sin Wiederruffra 1527 genkalder Denck således

73. $\quad$ Denck II.59.17-21. Sml. med Deut. Theol. \$42.

74. For Eckhart består eftergivenhed (Gelassenheit) i en venden sig væk fra det materielle for at finde sin indre sjælsgrund (Seelengrund), en lighed med Gud, som tjener som et umisteligt anknytningspunkt for åbenbaringen. Fx Quint, Meister Eckharts Predigten, I, 49-50; Packull 1977, 30; Hans-Jürgen Goertz, The Anabaptists (New York: Routledge 2008), 51; C. Windhorst, Täuferisches Taufverständnis (Leiden, 1976), 195f.). Packull placerer Müntzer i en mellemposition. Der er paralleler i Denck's og Müntzers spiritualisme, men i modsætning til Müntzer drejede Dencks tænkning sig i en anderledes pacifistisk retning.

75. Karl Holl, "Luther und die Schwärmer", Holl, Gesammelte Aufsätze zur Kirchengeschichte (Tübingen: J.C.B. Mohr (Paul Siebeck) $\left.{ }^{4} 1927\right)$, 420-467 (424).

76. Denck II.81-85.

77. Denck II.84.6-9. 
ikke sine overbevisninger, men pointerer, at han ikke (længere) anser spørgsmålet om dåb for afgørende. Alle sæder (Sitten), der som tegn viser hen på Gud, er sakramenter, men disse har kun sekundær betydning - eller måske er det mere præcist at sige, at for Denck er det eneste egentlige sakramente Kristi død og opstandelse, som gentages i ånden, og som kan få udtryk i noget, vi kan kalde "sakramenter". ${ }^{78}$ Dåb og nadver er ikke nådesmidler - det er kun Kristus.

Denck kan sagtens kaldes anti-dogmatisk frihedsforkæmper (Jones), men hans skepsis over for ortodoksi skyldtes ikke en humanistisk tiltro til fx menneskets medfødte dømmekraft, men en spiritualisme, som snarere bør kaldes anti-humanistisk: Anti-dogmatismen skyldes mistro, ikke tiltro, til menneskets dømmekraft. Mod Jones, Packull og andre må der indvendes, at da Denck ikke tilskriver mennesket nogen medfødt eller naturlig evne til at gøre det gode, kan hans menneskesyn næppe kaldes humanistisk eller "formet af den nye humanistiske forstålse af menneskets sande natur"79. Dencks krav om at løbe passivt (leydenderwey/S) beskrives af Bauman derimod helt korrekt som modsat al humanisme og naturalisme (Bauman 1991, 25). Selvom Denck også udfoldede sig som verdslig digter, er det også klart, at han ingen stor tiltro havde til menneskets iboende skaberkraft, som ifølge Denck for Gud snarere er ren destruktivitet. Hvad der for mennesket er skabelse (machen), er for Gud at bryde ned (brechen), og omvendt.

Et mere passende begreb til at karakterisere Dencks position kan være kritisk spiritualisme, for så vidt den drejer sig om den åndelige krise, som påføres mennesket af Guds dom. Det er dog væsentligt, at vi har at gøre med en minimalistisk spiritualisme, uden vilde profetier og visioner, som hos fx Hut og Müntzer. Spiritualisme betyder i tilfældet Denck simpelthen, at Kristi dom og nåde over mennesket sker umedieret i menneskets indre og derved fremkalder en krise, hvor mennesket bliver frit til at vælge mellem sig selv og Gud. Derudover egner betegnelsen kritisk spiritualisme sig til at karakterisere spiritualismens kritiske potentiale ift. ortodoksi, tradition, og så videre.

Dencks tænkning kan dertil forstås som et forsøg på at udfolde et teologisk kærlighedsbegreb. Gud er kærlighed, kærlighed er Gud. I krisen under Guds dom står valget mellem på den ene side egenkærlighed - hvad der for mennesket er noget, men for Gud intet - og på den anden side næstekærlighed - hvad der for mennesket er intet, men for Gud noget. Den, der tror, opfylder Guds Lov, selv når han bryder den, for loven er ophævet for den, som elsker Gud. ${ }^{80}$ Men net-

78. Denck II.62.33; II.80.36-38.

79. Jones 1914, 17-30 (min oversættelse).

80. Denck II.63.7-9. 
op kun kærlighed kan undskylde at bryde de af loven befalede sæder ("die sitten deß gsatz"), hvorved loven så at sige opsluges i kærlighed (jf. Dencks paradoksbegreb). ${ }^{81}$ Frelse består ikke for Denck blot i viljens ophør, som hos $\mathrm{fx}_{\mathrm{x}}$ Schopenhauer, men i at mennesket befris fra sin rettethed mod sig selv for i stedet med Guds vilje at kunne rette sig mod næsten. Da Guds vilje aldrig søger sit eget, synes menneskets kærlighed til Gud for Denck at være identisk med dets kærlighed til næsten..$^{82}$

Denck kan også kaldes en slags domsnaturalist, for så vidt Guds vrede er identisk med menneskets over for Gud selvpåførte fremmedhed, som indebærer sin egen selvudslettende straf. ${ }^{83}$ Gud straffer ikke retributivt, og Denck afviser derfor også en anselmsk forsoningslære, for Gud, som er kærlighed, forlanger ikke andet end menneskets omvendelse, skriver Denck. Men Dencks forsoningslære er heller ikke rent subjektiv. Gud gør omvendelsen mulig ved selv at blive det, som for Gud er intet, så mennesket kan blive det, som for Gud er noget. ${ }^{84}$ Som Bauman bemærker, er Dencks forsoningslære relationel og funktionel snarere end ontologisk (Bauman 1991, 29). Det handler ikke om, hvad der "faktisk" er, men om hvad der er muligt og umuligt for Gud hhv. menneske i deres relationer. Det er dog nok mere præcist at tale om en dialektisk-modal eller funktionel ontologi (hvor fx det onde er intet eller noget afhængigt af dets funktion).

Denck er pragmatist, hvis der derved forstås, at begreber som "sandhed" og "virkelighed" defineres ud fra "det, der virker". Teologi er for Denck hvad andre har kaldt theologia viatorum, altså teologi, som er sand, fordi den kommer fra og fører til sin genstand, uden derfor adækvat at beskrive sin genstand (Martensen). Tro handler ikke om intellektuel overbevisning, men om at adlyde Guds ord, til død eller til liv, med fast overbevisning ("gwisser zuversicht") om, at det er til det bedste. ${ }^{85}$ Enhver, der er Kristi discipel - og det kan alle være uden at have hørt om Kristus i det udvortes - overholder hele loven, selvom han aldrig har hørt om Moses. ${ }^{86}$ Kristendom er, for Denck, ikke et sæt mere eller mindre adækvate trossætninger, men et levet liv i kærlighed til Gud og næsten.

81. Denck II.81.6-8.

82. Denck II.33.3; II.94.1.

83. Denck II.92.17-22; II.98.14-20.

84. Denck II.76.26-29.

85. Denck II.97.17-18; Dencks trosbegreb adskiller sig altså fra fx en luthersk intellektualismes kærlighed til de "påstande" (assertionibus), som kristne må elske ifølge Luther, De servo arbitrio, WA 18,603,9-14.

86. Denck II.58.20-25. 